\title{
原著論文
}

\section{中国アパレルSPA企業における設計主務者の 意思決定プロセスに関する一考察}

\author{
李 宏偉*, 菅原 正博** \\ *浙江農林大学, **プロトビジョン
}

\section{A Study on the Decision Making Process of Chief Design Officer in the Apparel SPA of Chinese Company}

\author{
Hung-Wei LEE* and Masahiro SUGAHARA** \\ * Zhejiang A \& F University, Lin'an, Hangzhou, Zhejiang 311300, China \\ ** Proto Vision
}

\begin{abstract}
My subject is to analyze the characteristics of the Fashion Engineering in Chinese SPA company through the case study about the decision making process of the Chief Design Officer. The meaning of fashion designers is to segment the customer group set of its designer. Then, designer images the styling, fabric and item design of the customer set. Designer' job is to make decision of the design process. Through the case study of the Cocoon's Chief Designer Officer I could understand not only the leadership of the holistic branding decision making about the styling, fabric and item design but also the assortment and profit of the brand.
\end{abstract}

Keywords : Fashion design, Design director, Fashion engineering, Decision making, SPA

\section{1. 研究目 的}

本研究は, 中国アパレルSPA企業の設計主務者の意思決 定過程に関して事例研究を通して, 中国のファッション工学 的特色を解明することを扮もな目的としている. 今回の研究 では, 先行研究として信州大学が取り組んでいるファッショ ン工学的アプローチを中心に参考としながら, 一部, 欧州で 展開されている「ファッションデザイン」研究を参考にした いと考えている [1].

信州大学では「日本のファッション事業と国際プレゼンス」 の研究テーマのサブタイトルで「ファッション工学を標榜する」 とあるように,「ファッション工学」の研究体系の輪郭が 検討されている。 その予備的考察として, ファッション事業 における34個のキーワードが抽出されている.

このファッション事業のキーワードの中で, 中心的な役割 を果たしているのが，「設計主務者」である，ただこの 「設計主務者」の意思決定過程も，アパレル製造卸とアパレ ル製造小売りSPA とでは基本的に異なってくる. 本研究で は, 中国のSPA企業のファッション工学的特色を定性的に 研究することに重点を拉きたいと考えている.

\section{2つの先行研究}

\section{1 先行研究 1 信州大学の「設計者概念」}

今回の研究では, 先行研究として信州大学が取り組んでい るファッション工学的アプローチを中心に参考としながら,
一部，欧州で展開されている「ファッションデザイン」研究 を参考にしたいと考えている。まず信州大学の提唱する 「設計者」の概念を取り上げたい.

\subsection{1「設計者の概念」}

設計者の意味は，設計者の顧客となりうる部分集合を抽出 することにある。その上で部分集合 $\mathrm{A} の$ 典型的多岐な要素と なりうるモデルを着用者として想定し，その着用者の「形」 「姿」を指示する作業が絶対に必要とする.

この一連の作業がファッションの設計過程であり, 設計者が この作業を担う。こうした経験を積みながら，卓越した能力 を有する者が設計主務者となり衣服設計の方針を決定する.

\subsection{2 設計主務者の役割}

設計主務者は, この一連の設計過程 (=設計チェーン)の 結果責任を負う。ファッション衣料の設計過程で, 次の シーズンの出発点で「姿」「形」に関する基本の指示を出す. これを一次設計と呼ぶ。テーマ・コンセプト・エピソード. メモ・ポンチ絵など何でも良い

この主務者が提示する「姿」「形」を指示する着用者が多数 存在する。顧客名簿に搭載された顕在顧客として実在する。

この「設計主務者」の「姿・形」の概念をファッション 生活者から抽出する第 1 次設計に関する「設計主務者」の リーダーシップを出発点として, 次期シーズンの設計過程が スタートする。その簡単なプロセスを図式化すると，図 1 の ようになる.

この考え方の枠組みに，信州大学が提唱する基礎概念の 「ファッション事業」を構成する 15 個のキーワードをはめ込 むと, 図2のようになる。 


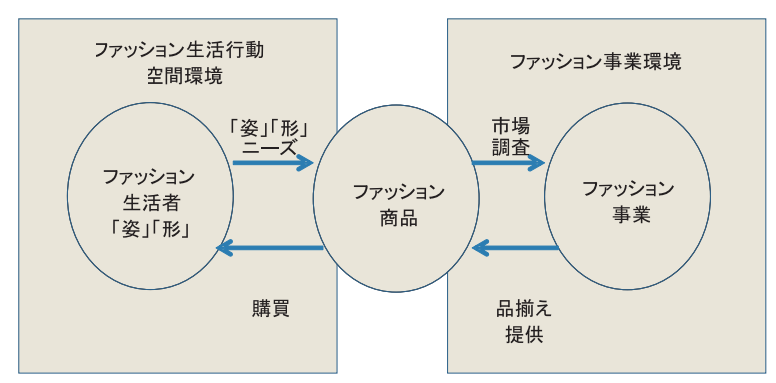

図1 ファッション工学の基礎概念

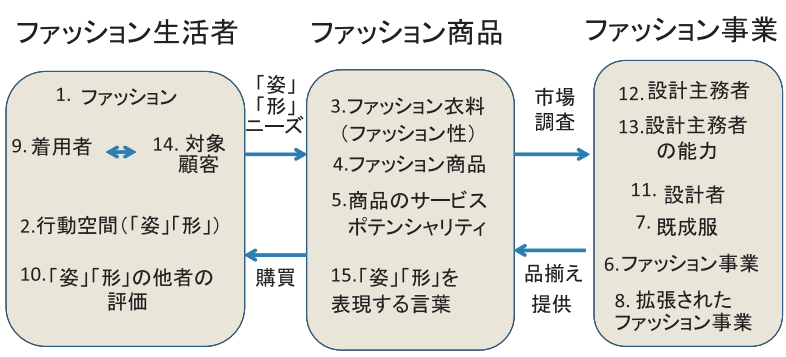

図2 ファッション事業の対象項目 (15項目)

\section{2 先行研究2 SPA型ビジネスモデル研究}

80 年代後半から 90年代にかけて日本のファッション業界で SPA (Special Retailer of Private Label Apparel) 型ビジネスモ デルが注目され始めた。日本では「アパレル製造小売」という 形で訳されているが，むしろ，この略語には「プライベート． ブランドのアパレル専門店」という意味合いが含まれている。

このSPA型ビジネスモデルでは，デザイン開発をする場 合には，自社の店舗に買いに来てくれる消費者を対象にして いる。

\subsubsection{SPA型ビジネスモデルの組織体系}

SPA型ビジネスモデルの組織体系を整理すると図3のよう になる。図3では,「ショップMD」が重要な役目を果たし, そのショップに対してコンスタントに商品フォローをし, ショップMDの商品回転率や消化率に責任を負う「ディスト リビューター」の機能とそのディストリビューターに各店の 売れ行き情報のPOS システムを通じてフィードバックする 情報システムを重視してきた [2].

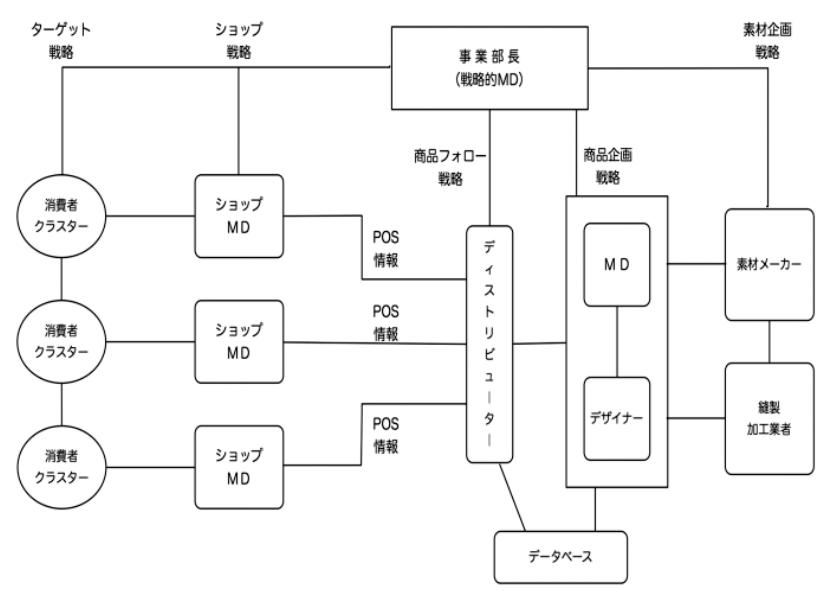

図3 アパレル製造小売り企業のMD組織
また売場の売れ行きにそって, オリジナルブランド商品を マンスリー単位やウイークリー単位で企画するデザイナー機 能も重視している.

SPA 企業は, 売場との間に取引が介在していないために, 売場の要望通りに商品を企画し生産することができる．SPA 企業では「ターゲット戦略」から「テキスタイル企画」まで プロセス的に一貫して連結されているために, 顧客の声が ダイレクトにサプライチェーンに反映される.

\subsection{2 消費者発想の垂直的プロセス}

消費者の要望に応えるような業務プロセスを企画しない と, 幾らアデザイン開発が的確でも, 価格の安さに負けてし まう，という競争環境が支配的になってきた。米国では不況 が長引いた 80 年代にこういった SPA型のビジネス・モデル が競争力を持ち始めたが, 日本では, 90 年代後半に入って, 同じく不況が長引いている時期にSPA型ビジネスモデルが 注目され始めた

この消費者発想の垂直的プロセスを図式化すると図4のよ うになる

SPA企業は，どのような商品を企画し顧客サービスを行 うかという MD企画と, 生産, 配送, 販売のロジスティック・ オペレーションをシステム化しているために, 顧客満足とい う点ではNBブランドのアパレル製造卸売企業よりもはるか に競争力がある.90年代に注目されたSPA企業のビジネス・ モデルは, その当時のファッション・マーケティングを事業 システム化した高次元の戦略で合ったといえる.

\subsubsection{SPAを支える5つの要因}

21 世紀にはSPA以外は生き残れないといわれているが,

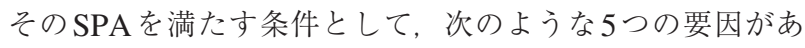
げられる。

1）オリジナル企画

2) 自社生産

3) 自社オペレーション

4) VMD（ビジュアル・マーチャンダイジング）

5) QRS（クイック・レスポンス・システム）

独自性を出すためには，誰のための店であるかが具体的に 明確になっていること，テイストが限りなく絞込まれている ことが条件である.

したがって，SPAにとって重視する必要があるのは, オンリーワンコンセプトである。他にないユニーク性が絶対 条件である。幅広いターゲットから限定されたターゲットに 強くアピールする必要がある。

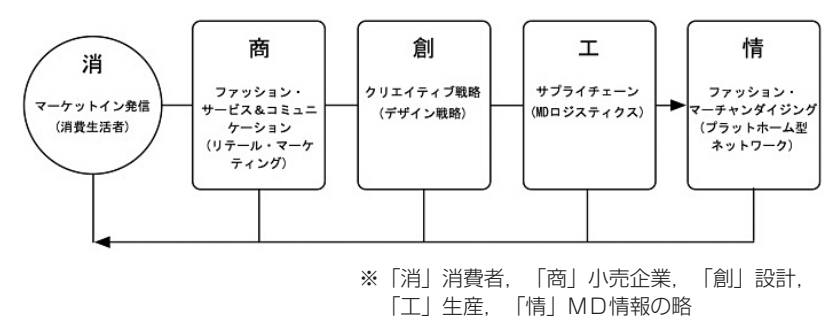

図4 消費者発想の垂直的プロセス 


\section{3. 研 究 方 法}

中国を代表するアパレル SPA 企業であるCocoon を事例と して研究を進める.

\subsection{Cocoon ブランドについて}

ブランド名Cocoonはコクーン・網の意味で, すべての 女性の一生は蝶のよう進化の過程と考え, ずっと頑張って望 む中国女性に，ファッションを通じて独自の優位性を見つ け，洗練された，優雅な女らしさを身に付けた，より魅力的 な女性像を提案する。ややセクシーなイメージも加味されて いる.

また，東洋の女性の魅力に自信を持ち，独立職場で活躍し ており，街を歩くことも，素敵な女，優雅な女性像を理想と する。

Cocoonブランドは25-35歳の成熟優雅な都市の女性を ターゲートとしており，女らしい，女性の独立性を見せる， 女性たちの独特な個性, または成功した女性をイメージした 商品を展開する。

他社と違う差別化され商品には個性が目立つ。

消費者が購買する製品だけでなく，ブランドの歴史と一つ のライフスタイルを提示する。

製品の分類としては,

1）高級注文シリーズ…スター, 著名人などをターゲット

2）高級シリーズ…ファッション雑誌に発表, テーマ物語 シリーズ

3）成衣シリーズ…コンセプト提案

4）優雅な都会なイメージ

5）柔らかな女らしいイメージ

6）週末のカジュアルシリーズを提案

7）アクセサリーを提案

8）女児姫シリーズを提案

等が挙げられる。

また, Cocoon製品の主な特徵として，下記の 4 点が挙げ られる。

・優良な品質…ハイエンドブランド品質の製品はその価格 の合理性を証明する。

-手頃な価格の高級ファッション…手頃な価格にもかかわ らずCocoonはハイエンドブランドで, 価格帯が広い.

・国際化のスタイル…当社のブランドの任務は西洋のトレ ンドを中国に持ち込む，優れた製品を作り出している。

・高級なデザイン…゙゙ザインは実用的だけではだめで, シンプルすぎでもよくない, かつユニークなアイデアが 必要.

\section{2 設計総監へのインタビュー調査}

先行研究で重要性を明らかにした「設計主務者」の職務内 容を明らかにするために, 以下の16項目について, Cocoon ブランドの設計主務者（中国では設計総監という）に2015年 8月 2 日に, Cocoonのデザイン室でインタビュー調査を行った.
質問 1 現在, Cocoonブランドの設計責任者として，どの 程度の範囲の仕事に責任を持っていますか.

質問 2 設計部門のスタッグの管理責任の範囲はどこまでを 含んでいますか.

質問 3 次期シーズンの企画は，いつから始めますか.

質問 4 次期シーズンのテキスイル・デレクションテーマの 選定.

質問 5 テキスタイル企画と選定に関して，設計責任者はど こまで参画しますか.

質問 6 次期シーズンの企画の設計に関して,「ファッショ ンショー向け」に何デザイン数を企画しますか.

質問 7 次期シーズンの展示会用に何デザイン数を企画しま すか.

質問 8 Cocoonブランドの顧客ターゲットは, 会社の中で 誰が決定していますか.

質問9 Cocoonブランドの在庫管理面で，よく売れている 商品の在庫と売れ行きが悪い商品やデザインの情報 は定期的に設計責任者も，コンピュータデータとし てよく活用していますか.

質問10 Cocoonブランドの直営ショップの場合のデザイン 企画は, そのショップの各陳列什器や売り場の面積 を想定して，デザイン型数を決めていますか.

質問 11 この場合, 新規のトレンド商品のデザイン型数と継 続型のベーシック商品のデザイン型数の割合の比率 はどのくらいですか.

質問 12 Cocoonブランドでは, 春夏企画と秋冬企画とでは, ワンピース，スーツ，コート，スカート，パンッ， ダウンジャケット, ブラウス, シャツ, カットソー, 靴，バッグといったアイテムデザインの比率がかな り異なると思いますが，年間を通して一番よく売れ るアイテムを金額面の大きさの順に並べると，どう なりますか.

質問 13 春夏，秋冬のそれぞれのシーズンで，デザイン企画 の出発点でデザイン責任者から，何テーマを打ち出 していますか.

質問 14 設計企画を始める際にデザイン設計のテーマを打ち だすにあたって, どんな情報を参考にしていますか.

質問 15 Cocoonブランドが, 各都市の百貨店や路面店で最も 競合するブランドはどこの企業のブランドですか.

質問16 現在，中国でもインターネットやネットショップの 影響力が高まってきていますが, Cocoonブランド は, どう対処していますか.

\section{3 コレクション評価}

「ファッション工学」の概念を参考にして,「着用者」によっ て支持される「姿」「形」に関する設計主務者の表現力につ いて以下のように定義できる.

「設計表現力」とは,「姿」を「スタイル」で表現し， 「スタイル」の「原型」を表現した「シルエット」に分類し， 平面体の「ファブリック」の魅力を生かして，「上身頃」と 


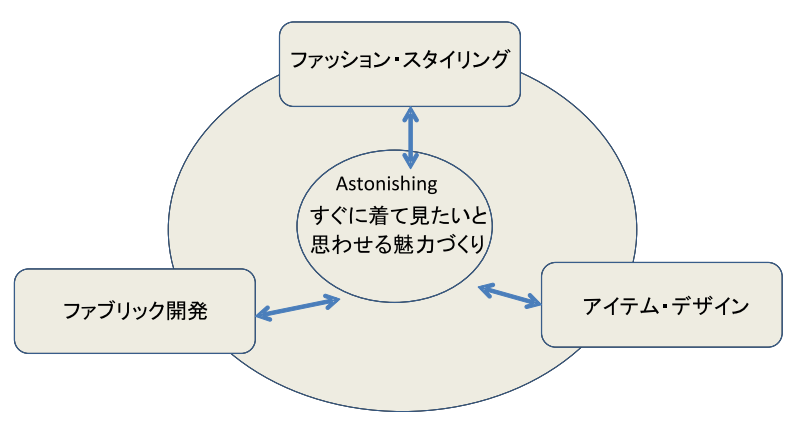

図5 Astonishing感性リッチ価値提案システム

「下身頃」に分けて，「アイテムデザイン」のハンガーイラス トまたはクロッキーを作成し, 選定する能力を意味している。 設計主務者は，「姿」「形」を見える化するために，「ス夕 イル」「ファブリック」「アイテムデザイン」の3つのバラン スの表現力をシーズンごとに磨き続ける必要がある.

このバランス関係を図式化すると, 図5のようになる.

Astonishing とは「驚き」の意味で, 着用者自身の「驚き」 だけではなく,「着用者」を取り巻く周囲の人々の「称賛」も, この「驚き」の概念に含まれている。したがって「驚き」は 周囲の人々の「要求水準」Aspiration Levelや期待值を超え るインパクトのあるものである必要がある $[3,5]$.

そうした「驚き」のある「姿」「形」であると，「すぐにで も着たい」という衝動を呼び起す魅力を持った表現力と評価 される。

この「魅力度」を評価するにあたって, 設計主務者が最終 決定した「コレクション」の各スタイルを「スタイリング」 「ファブリック選定」「アイテムデザイン」の3つの要素のう ちで, どの要素の「魅力度」が高いか, というランク付け調 査を行った。 その評価表は, 図6に示すように, スタイリン グの写真を提示し, それぞれに魅力度の高い要素を順に挙 げ,コメントを記入する形式とした。

今回は 2015 年秋冬のコレクションから 24 スタイルについ て, Cocoonの設計総監と日本のファッションディレクター の 2 人に, 2015 年 8 月に調査を実施した.

\section{Styling 1}

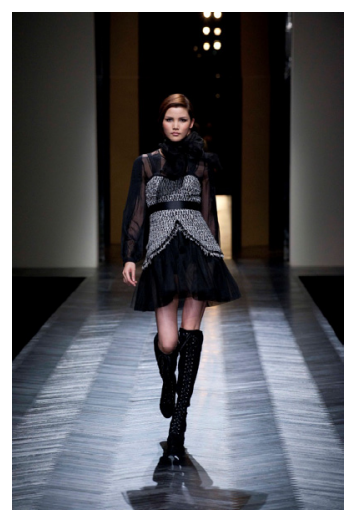

- 3 Criterion of Style Selection : Styling, Item Designing, Fabric

First Rank \& Comment

Second Rank\& Comment

Third Rank \& Comment

図6 コレクション評価表

\section{4. 研 究 結 果}

\section{1 設計総監へのインタビュー調査}

Cocoonブランドの設計総監に行ったインタビュー調査の 結果は以下のとおりである.

質問 1 各シーズン前のブランドのファッションディレク ションから,売上および利益まで責任を持っている.

質問 2 デザイナー管理だけではなく, 素材選定, パターン 作成，サンプル縫製まで管轄している.

質問 3 シーズンが終わった段階から 1 年先の企画を監視する. 質問 4 シーズンが始まる 1 年前のテキスタイル展示会に出 席したり，主力テキスタイル納入業者のプレゼンを 受けて, テーマを決める.

質問 5 次期シーズンのテキススタイルの選定は，各担当の デザイナーの要望を取り入れて, 最終的に設計総監 が決める。（図7参照)

質問 6 約 50 型を企画する.

質問 7 約 150 型を企画する.

質問 8 営業の意見を聞きながら, 設計総監が決めている.

質問 9 品番ごとの売れ行き状況を見て, 追加生産や在庫調 整に設計総監も参画している.

質問 10 直営ショップは, 各陳列什器でコーディネット提案 をするために, カセットの形でデザイン品番を決め ている。

質問 11 新規が3割, 継続品が7割で企画している.

質問 12 秋冬の場合は, ワンピース, スーツ, コート, ダウ ンジャケット，パンッ，スカート，靴，バッグが主 流で, 春夏の場合は, ワンピース, パンッ, ブラウス, シャツ, カットソー, 靴, バッグという順である.

質問13 だいたい，5〜7テーマを出している.

質問 14 ヨーロッパのテキスタイル・デイレクション情報と パリ，ミラノコレクション情報を参考にしている。

質問 15 江南衣料のJSBYやONLY, ZARAなどである.

質問 16 Cocoonでもアリババグループの天猫モール東商城 といったネットショップ展開に力を入れている.

\section{Styling 1}

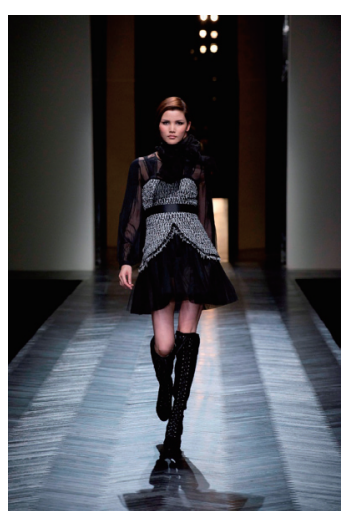

スタイリンク選定の 3 つの基準：スタイリンタ、 アイテムデザイン、ファブリック 第1位: ファブリック

コメント

質感の違う異素材使いがおもしろい。クラシック素材 とフェミニン素材の融合バランスが印象的

第2位: アイテムデザイン

コメント ピスチェを重权着したようなデザインが女性らしい。

第3 位: スタイリンタ

コメント

編み上げのニーハイブーッとの組み合わせがレトロ でかわいい 


\section{2 コレクション評価}

Cocoonのコレクションの中から24スタイルを選んで, それぞれの「スタイリング」「ファブリック」「アイテムデザ イン」の3要素について, 中国の「設計主務者」と日本の 「ファッションディレクター」に評価をしてもらった。（図7） その結果を表 1 にまとた。 なお，紙面の都合上，24スタイ ルのうち，5スタイルの結果を掲載する。

\section{5. 考 察}

今回, 調査の対象として選んだCocoon社の設計総監と 企画室でインタビューを行った風景の写真を図9, 図10で紹介 しておいた。この「設計総監」のインタビュー調査とファッショ ンデザイン調査を踏まえて, 中国アパレル企業のファッション デザインに関する「設計主務者」の意思決定プロセスの特徵 を整理すると，以下のようなことがいえる.

\section{表1 スタイリングNoごとの中日対比分析}

\begin{tabular}{|c|c|c|}
\hline スタイリング No & 中国の設計主務者の評価 & 日本のファッションディレクターの評価 \\
\hline No1 & 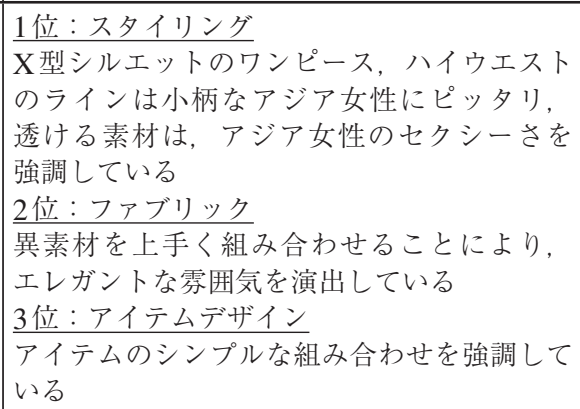 & $\begin{array}{l}\text { 位: ファブリック } \\
\text { 質感の違う異素材使いが括もしろい. クラ } \\
\text { シック素材とフェミン素材の融合バランス } \\
\text { が印象的 } \\
\text { 2位:アイテムデザイン } \\
\text { ビスチェを重ね着したようなデザインは女ら } \\
\text { しい } \\
\text { 位:スタイリング } \\
\text { 編上げのニーハイブーツとの組み合わせが } \\
\text { レトロでかわいい }\end{array}$ \\
\hline No2 & $\begin{array}{l}1 \text { 位: スタイリング } \\
\text { クラシックな } \mathrm{S} \text { 型シルエットは女性が好き } \\
\text { で, パーフエクトでない分, きれいに見える } \\
2 \text { 位: ファブリック } \\
\text { 異素材の組み合わせ, 素材全体がソフトで, } \\
\text { 冬シー゙ンのロマンティックな雰囲気を演出 } \\
\text { している } \\
\text { 3位: アイテムデザイン } \\
\text { 組み合わせの仕方で, 上から下に向けてグラ } \\
\text { デーション化している }\end{array}$ & $\begin{array}{l}\text { 1位:アイテムデザイン } \\
\text { クラシカルなペプラムディテールが女性らし } \\
\text { く,このトップスだけで着こなしが仕上がる } \\
\text { 2位：ファブリック } \\
\text { 襟, ペプラムの異素材使いが特徴的 } \\
\text { 位：スタイリング } \\
\text { 透け感のボトムとの組み合わせが新鮮で全体 } \\
\text { のシルッが美しい }\end{array}$ \\
\hline No3 & $\begin{array}{l}\text { 1位: スタイリング } \\
\text { 同系色を組み合わせたシルエットを活用し } \\
\text { て, トレンド感を演出している. } \\
\text { 2位: アイテムデザイン } \\
\text { 暖かいファブリックとショールの組み合わせ } \\
\text { が特徵で, フェミニンなイメージを演出して } \\
\text { いる } \\
\text { 位: ファブリック } \\
\text { セパレーツになっているために, 組み合わせ } \\
\text { を変えていろいろな着こなしが楽しめる }\end{array}$ & 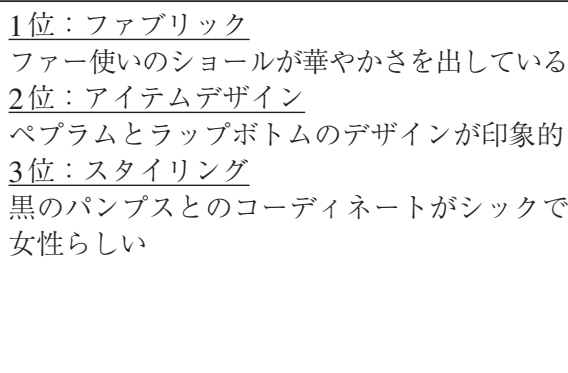 \\
\hline No4 & 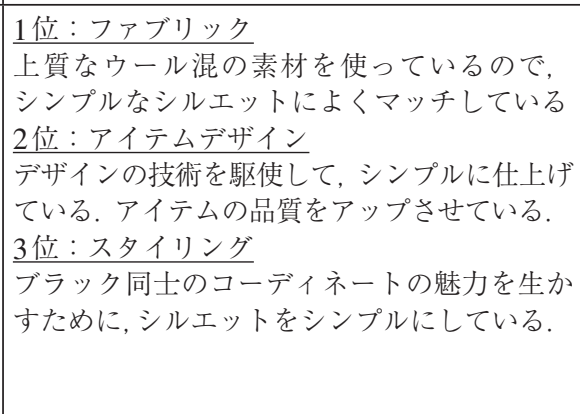 & 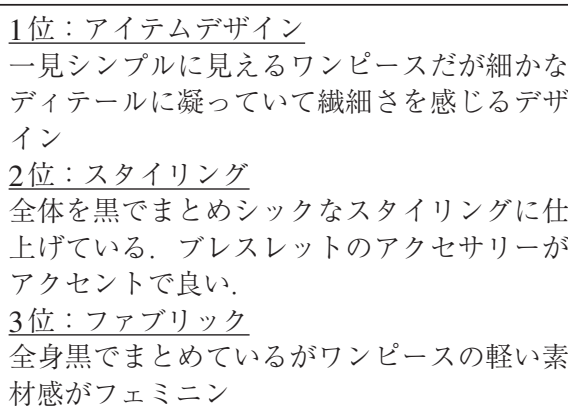 \\
\hline No5 & $\begin{array}{l}\text { 1位:アイテムデザイン } \\
\text { 顧客の多様なニーズに対応するために, 顧客 } \\
\text { のオケージョンスタイリングを重視している } \\
\text { 2位:スタイリング } \\
\text { 働く女性の女らしさを支援する素材や色を重 } \\
\text { 視している } \\
\text { 位: ファブリック }\end{array}$ & $\begin{array}{l}1 \text { 位: スタイリング } \\
\text { モノトーンのアウターに赤と黒のサンダルス } \\
\text { タイルがモダン } \\
2 \text { 位:アイテムデザイン } \\
\text { ショート丈ベストがアクセントになり印象的 } \\
\text { 3位: ファブリック } \\
\text { 異素材の各アイテムがバランスよく調和して } \\
\text { いる }\end{array}$ \\
\hline
\end{tabular}




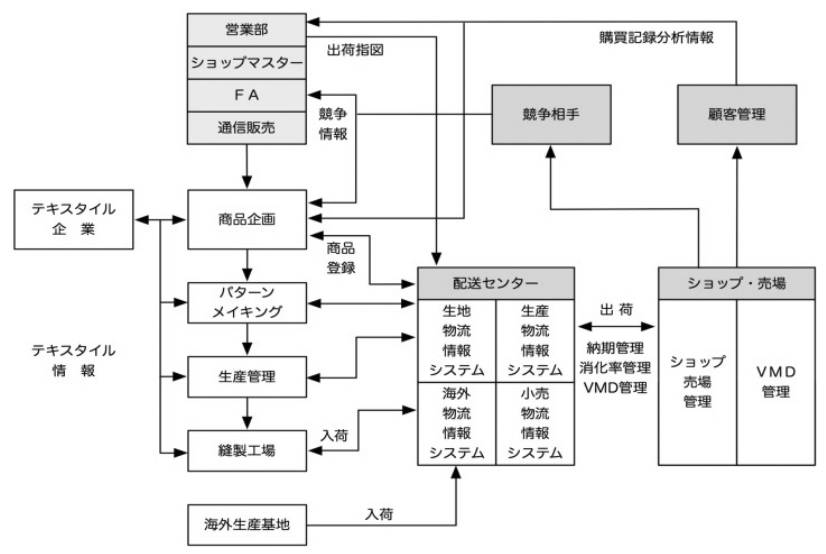

図8 ファストファッション戦略

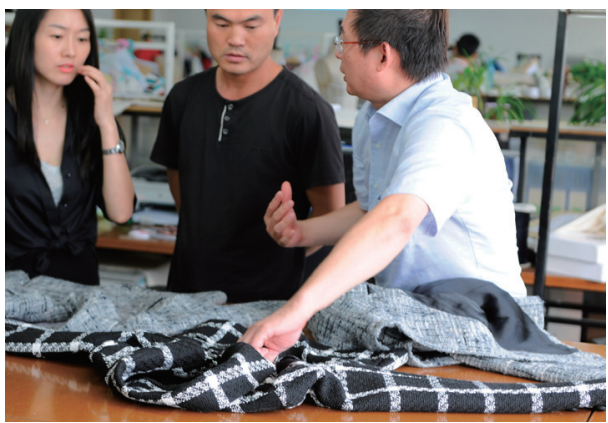

図9 設計総監とのインタビュー風景

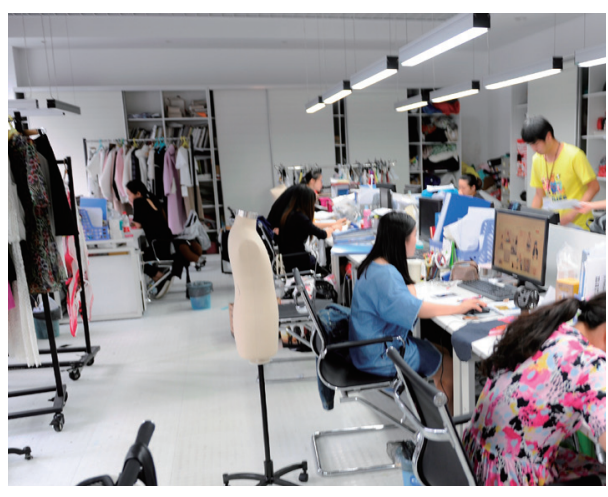

図10 設計室

同社のブランドターゲットが, 中国の働く女性の通勤着を 主体に狙っているので, 路面店及び百貨店のインショップに 買い物に来る消費者のワードローブを第 1 次設計段階から, 「設計総監」がファッションディレクションとファブリック 又を考慮に入れて, 店頭の消化率を考えて, 品揃えの形を考 慮して, 設計チェーンを管理する責任を持って運営している ことが，把握できた。

図 8 は垂直的プロセスの進化形で, ファッションの短サイ クルとテキスタイル企業との連携をより強めた「ファスト ファッション」のビジネスモデルをイメージ的に表現したも のである

ファッションの短サイクルとテキスタイル企業との連携を より強めた「ファストファッション」のビジネスモデルを イメージ的に表現したものである [2].

\section{1 ファッション工学の領域}

日本の場合, 日本で消費される衣料の $95 \%$ が輸入依存で あるばかりか, 日本のファッション事業の国際プレゼンスは そしい，信州大学ではこの問題に関して，技術的経営的な側 面から検討を加えてきた。そして「製品設計」がその原因の 1つではなかろうかと考えるに至った。

ファッション工学の対象は人間の身体表現行為そのもの にあり，最終的には混とんとした大空間から抽出してきた 部分集合によって説明される対象顧客の行動範囲における 「姿」「形」である。ファッション工学は身体表現に有用な ファッション商品の設計製造販売に係る問題に寄与すべき である。

\section{2 身体表現の行動空間と市場細分化戦略}

「姿」「形」の行動空間が類似しているグループを層別に捉 えて「特定のターゲット」を選定し，そのターゲット層に向 けた「ファッション事業」を審議・承認するのは, 経営トッ プの仕事である

ただ,この場合, 設計主務者が, 自己の特異性を生かして, なおかつ，最終的に利益を確保できる「対象顧客」を経営 トップに提言し, その「対象顧客」に対する「ファッション 商品」を企画・生産・販売することを通じて, 安定した利益 を確保し，そのファッション事業に投資した資金を一定期間 内に回収可能であると判断した場合には,「設計主務者」と して最終的にシーズンの企画内容を意思決定する.

\section{3 ファッション工学の課題}

特定ターゲットが受け入れる「姿」「形」の「行動空間」 を表現した「ファッション商品」を企画・生産・販売するこ とを通じて, 実際に「特定ターゲット」の「着用者」が満足 し，なおかつ，その業務に欠けたコストを上回る収益を生み 出すプロセス全体を設計することを「ファッション工学」と 定義することができる.

この「ファッション工学」は欧米では「ファッション・マー ケティング」と呼ばれている概念に近い. 日本では, この 「ファッション工学」の企画プロセスを「商品企画」と呼んで きたが, 欧米でも「Product Development」と呼んでおり, ファッション・ショウで提示する「商品企画」を「ファッション・ デザイン」と呼んで抒り，その設計責任者を「設計主務者」 または「デザイン・マネージャー」とも呼んでいる $[4,6]$.

\section{6. 結論と今後の展望}

中国アパレル企業の「設計総監」の意思決定過程に関する 実証研究を通じて, 中国アパレル企業ではファッション工学 的特徴を備えていることが確認できた。

今回は, 特定のアパレル企業に限定して定性的調査を行っ たが, Cocoonブランドの設計総監は, このブランドの創設 以来, 15 年にわたって設計主務者を担当しており, ブランド の第 1 次設計とそれを消費者の購買に結びつけ, 各シーズン 
ごとの在庫管理から利益責任まで経営トップ共有ということ がヒアリング調査を通じて確認できた。

逆に日本のアパレル企業では，こういった「設計主務者」 の存在を必要としないまま, MD主導型で展開してきたとい う意味では, 中国杭州のアパレル SPAのほうが, ファッショ ン工学の特色を備えている企業が排出している，という知見 が得られた $[7,8]$.

同じ杭州で早くから高級ブランド企業として成長してきて いる江南衣料のJNBYブランドは，すでに日本市場で展開し ており，国際プレゼンス力を高めつつある [9].

この江南衣料も,「設計総監」制度を積極的に取り入れて おり,「ファッションデザイン」と「ファブリック選定」を 第 1 次設計レベルにおいて, 経営的視点を加味した意思決定 をして成功してきている企業の一つである。

また中国杭州地域だけはなく、アパレル SPA企業の動向 は，香港，広州，深せん地域でも活発化しつつあり，ブラン ドの経営に推進責任を持つ「設計総監」の役割が高まりつつ ある。

中国では，アパレル流通過程で，日本のような商社やアパ レル卸商の介在する余地が少なかったために，世界標準の ファッション工学が, インターネットと結びつきながら, リアル店舗とネットショップを通じて, 直接, 顧客の姿・形 に関する感性知識を共有しながら，今後，アジア全領域にわ たって,「国際的プレゼンス」力を高めていく可能性が高い と推察できる。「国際プレゼンス」を高める一つの手段とし て，「感性工学」の「気分分析」を重視する必要がある [10].

\section{参 考 文 献}

[1] 大谷䧫, KyongOk KIM, 高橋正人, 乾滋, 森川英明, 高寺政行：日本のファッション事業と国際プレゼンス ファッション工学を標ぼうする, 感性工学, 12(12), 2015.

[2］菅原正博：ファッションバイヤーMD，ファッション教育社, 1995.
［3］李宏偉，菅原正博：感性リッチ型時代にけるSACAI Brand Designingの仕組み テキスタイルの魅力度分析を中 心にして, 日本感性工学会, 第17回日本感性工学会大会, 大会口頭発表, 2015 .

[4] H. Carr, J. Pomeroy: Fashion Design and Product Design, Blakwell, 1992.

[5] S. Mower (ed.): Sacai A to Z, Rizzoli, 2015.

[6] R. Sorger, J. Udale: The Fundamentals of Fashion Design, AVA Academia, 2008.

[7］炭釡啓人, 菅原正博（監）：ファッション・デザイン・ ハンドブック, 平成 21 年度文部科学省研究助成, 教育· 学習方法改善支援報告書, 宝塚大学, 2009.

［8］崎田喜美枝：ファッションブランディング, 宝塚造形芸術 大学出版局, 2006 .

［9］大谷毅，高橋正人：テキスタイルメーカーの製品設計にみ る front loadingについて, 第 17 回日本感性工学会大会, 大会口頭発表, 2015.

[10] 椎塚久雄: 売れる商品は感性工学がある, ベストセラーズ, 2013.

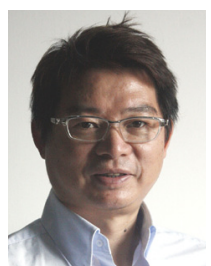

\section{李 宏偉 (学生会員)}

2004 年 京都精華大学芸術学部卒業. 芸術学 博士 (宝塚芸術大学)。宝塚大学東京メディ ア・コンテンツ学部非常勤講師, 中国浙江農 林大学専任講師, 中国美術学院中国・ドイツ 大学院非常勤講師.

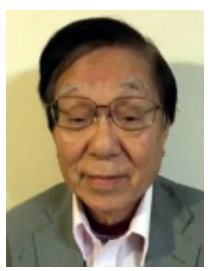

菅原 正博（正会員）

1959 年 大阪市立大学経済学部卒業. 経済学 博士 (大阪市立大学)。宝塚大学専門職大学 院デザイン経営研究科研究科長定年退職後, プロトビジョン代表を務める。 日本感性工学 会理事を経て、参与を務めているが，同学会 の「企画セッション」の「感性知識マネジメント」部会の主査 を担当している. 中国浙江農林大学の客員教授. 